\title{
The Fourth-Century Tax Roll in the Princeton Collection
}

\author{
Roger S. Bagnall (New York) and Klaas A. Worp (Amsterdam)
}

In the course of our work on chronological problems of later Roman Egypt; we found much of interest in the long roll published a half-century ago by Edmund H. Kase, Jr., as his dissertation (A Papyrus Roll in the Princeton Collection [Baltimore 1933]) and subsequently reprinted as $S B V 7521$. We found that in a number of key places the published readings caused difficulties of interpretation, and we were able to check these on a visit to Princeton in 1980. Subsequently, we became convinced that there were other problems in the edition, particularly in the erucial matter of the reading of tax names, and we obtained through the kind offices of Professor Ann Filis Hanson a good set of photographs. After study of these, we concluded that a complete republication of the text, with a new introduction and notes, would be warranted; we visited Princeton again in 1982 in order to verify readings. The results of this investigation are presented below.

\section{Physical Description and Scribal Hands}

The Philadelphia tax roll published by Kase and republished here has been preserved in five large pieces in the Princeton collection and one smaller one in the Cornell collection. For the reader's convenience, we reproduce here Kase's description of the papyrus; a few supplementary remarks by us are placed in square brackets.

The roll has an average height of thirty-three centimeters, except in the case of the smaller fragments, which have been damaged either at the top or at the bottom of the column. The total horizontal length of the extant fragments is two meters, twelve centimeters. ${ }^{1}$ ) In addition an approximate allowance of twenty-five centimeters must be made for the missing fragments from Cols. XI and XII, bringing the total length to only a little less than two and one-half meters. The four letters found, however, at the extreme left edge of $\mathrm{Col}$. X, representing a small fragment of a preceding column, indicate that at least one column has been lost from this end of the roll. [Kase notes, p. 3, n. 4, that the letters at the left of Column $x$, opposite line 13, are $\alpha \tau \omega$, which he

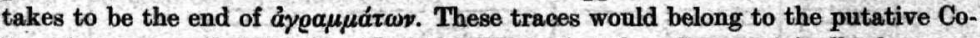
lumn ix ; see our sketch below.] It is thus likely that the roll was originally three meters or more in length.

Columns were added to the text from left to right. [The scribe began at the left end of the roll, that is; there is no good reason to suppose that the pieces of papyrus were glued on only as used.] After the completion of nine columns the roll was reversed and the scribes commenced to fill in the roll from the opposite end. Col. XIV, the last column entered on the roll, thus stands in an inverted position at the bottom of Col.

1) The six fragments have the following dimensions: AM 8954, $159 \times 33 \mathrm{~cm}$.; AM 8954 A (Col. X), $17 \times 30 \mathrm{~cm}$.; AM 8954 A (Col. XII), $19 \times 31 \mathrm{~cm}$; AM 8955 (Col. XI), $4^{1 / 2} \times 17 \mathrm{~cm}$.; AM 8956 (Col. XIII), $6^{1} / 2 \times 31 \mathrm{~cm}$; Cornell Inv. 113, ca. $6 \times 31 \mathrm{~cm}$. 
IX. ${ }^{1}$ [The traces adjacent to Column xiv are oriented in the same way, so that the bottom of Column ix ${ }^{2}$ was evidently also used upside-down as Column xiv ; see our sketch.]

Of the various fragments, the largest piece, AM 8954, contains Cols. I-IX (including Col. XIV = Col. IX inverted). AM $8954 \mathrm{~A}$, consisting of two rather extensive fragments, furnishes two detached columns, $X$ and XII. The two smaller fragments grouped together under AM 8955 supply portions of Cols. XI and XIII. The Cornell fragment (Inv. 113), containing the final letters of the lines of Col. X, preserves in an addition an intercolumnar margin and the initial letter upsilon from the seventh line of the succeeding column. Only the fragments representing Cols. XII and XIII can be joined together perfectly. Elsewhere the extant fragments are separated through the loss of small sections of the roll.

Writing is found only on the recto, seven hands being distinguishable. The granary receipts as well as those issued to cover the payment of transport dues are principally in the clear, legible hand of Aurelios Alypios (Hand 1). These make up approximately half of the extant text and include Cols. I (except lines 19-25), II, IV, VI, VII (except line 12), VIII (except lines 1-8), X, and XI. The remaining granary receipts were written by Melas (Hand 6), Cols. XII and XIV (lines 13-16), or by an unknown hand (Hand 7), Cols. XIII and XIV (lines 1-12). Next to that of Alypios the most extensive hand (Hand 4), and likewise the most difficult to read because of its extremely cursive character, is that represented by the receipts for money payments found in Cols. III, V, VIII (lines 1-8), and IX. [Hand 4 is also found in the "Column

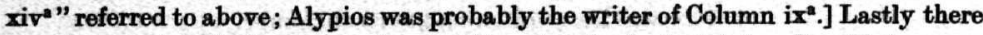
are the receipts fortransport dues written by the bouleutai Aurelios Neilammon (Hand 2), Col. I (lines 19-25), and Aurelios Dioskoros (Hand 3), Col. I (margin). The signature (Hand 5?) in Col. VII (line 12) was probably written by one of the kephalaiotai, though the hand strongly resembles that ascribed elsewhere to Melas.

N. B.

1. Change of hands is not indicated in the printed text of the roll.

2. Lines $34-35$ in the $S B$ reprint of the text should have been 33-34; we have kept the original numbering in order to prevent confusion with citations to the $S B$ text.

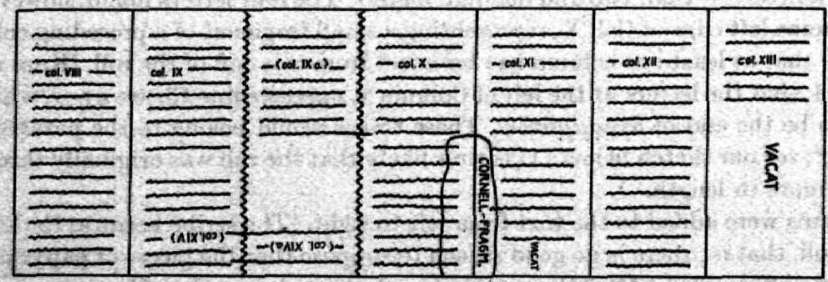

P.Prine. Roll, cols. Vill - XIV

1) [It is not elear what Kase means by this. Certainly Column xiv dates not only after ix but after its successors as well, so that the turning for reuse may come well after ix. The missing "xiv" may well be earlier.] 


\section{The Arrangement of the Tax Roll}

The general question of the method by which the more extensive tax rolls and parts thereof which have survived to us were composed was treated by Bagnall in $P$. Col. VII, pp. 70-75, principally in connection with the Karanis archives of the middle of the fourth century. In the present section, we will set out briefly how we see the Philadelphia tax roll, and in an excursus at the end of the present article we treat a number of other such fourth-century texts.

Read from start to finish, the tax roll hardly appears to be in chronological order. But the method whereby the writers of the receipts used the roll brought to them by the taxpayer can be seen clearly enough. One may distinguish seven major phases:

1. First wave of writing, in which the first four columns were begun: i, ii. 1-16, iii. 1-9, and iv. 1-10. This process extended over the period from August, 311, to August, 313. Except in Column i, scribes tended to start a new column each time the taxpayer appeared before them, rather than to use unfilled space.

2. First filling in, in which the empty spaces created in phase 1 were used up: iv. $11-21$, ii. $17-21$, iii. $10-24$, ii, $22-24$. There is no reason for these columns to have been used in chronological order, since a receipt-writer would simply pick an open space he liked. This process lasted from June, 314, to August of the same year, and st its end there was no space left in columns $i$-iii. The small text squeezed in between $i$ and $i i$ belongs somewhere in this period, we suppose, but its writing cannot be dated.

3. Second wave, in which columns $v$ and vi were opened up (v. 1-12, vi. 1-11), during July, 315.

4. Second filling in, with the remainder of $v(13-16)$ used in August, 315.

5. Third wave, in which columns vii $(1-12)$, viii $(1-8)$, and ix $(1-5)$ were opened up, from September, 315, to January, 316.

6. Third filling in, with iv. $22-28$, ix. $6-12$, vi. $12-22$, and viii. $9-21$, between February, 316, and July, 317.

7. Fourth wave, in which the receipts are all in strict chronological order, taking us up to June, 324. It should be pointed out that there was originally a column after ix, which is now almost entirely missing. It was in the same vertical position as xiv, to the right of which it stands, and it seems to be in the handwriting of the moneytax collector of lines $60-83,115-129,164-171$, and $185-196$. The remaining traces include ] $\tilde{\alpha} \tau \omega v$, which would suit the consulate of 317 (a year missing from the roll in just this place), and another line may be read $\delta c] \varepsilon \gamma \varrho(\alpha \psi \varepsilon v)$. Cf. supra, p. 53, for Kase's physical description of the roll.

\section{The Tax Payments}

The table below sets out the various tax payments recorded in the roll. It will be remembered that there is a missing column ("ix ") and some parts of other columns sufficiently damaged to allow the hypothesis that some tax payments stood there. Nonetheless, it is elear that the roll cannot have included all payments made for all of these taxes throughout the period $311-324$. The grain payments are indeed almost complete, with barley missing in three years. Adaeratio, however, is missing for $313 / 4$ and for all years from $315 / 6$ on, even though the fairly consistent levels of grain payments in those years compared to $314 / 5$ suggest that some payments in cash for grain 


$\begin{array}{ll}\begin{array}{l}\text { For Year } \\ \text { 309/310 (18) }\end{array} & \text { Wheat } \\ \begin{array}{l}310 / 311 \\ (19-7-5)\end{array} & 751 / 2 \text { art. (7) } \\ & \\ 311 / 312 & 931 / 2 \text { art. (42) } \\ (20 / 8-6-4-2) & \end{array}$

\section{$312 / 313$ \\ (21/9-7-5)
$313 / 314$
$(22=8-6)$ \\ $314 / 315 \quad 54$ art. (135) \\ (23/ind. 3)}

Barley.
$711 / 2$ art. (8)
$531 / 3$ art. (44)

Adaeratio

$4148 \mathrm{dr} . / \mathrm{b}$ (71) (in 314)

$5152 \mathrm{dr} . / \mathrm{w}(73)$

1 T. 3864 dr./e (76)

(both in 314)

193 den./w (192) (in 316)

300 dr./b (74) (in 314)

2 T. 50 den./b (193)

990 den./b (195)

(both in 316)

1 T. $3864 \mathrm{dr} . / \mathrm{c}$ (78) (in 314)

36 art. (92)

5 T, 2200 dr./b (75)

1 T. 3864 dr./c (80)

(both in 314)
$315 / 316$

(ind. 4)

53 art. (147)
51 7/12 art. (99) $311 / 2$ art. (100)

33 art. (149)
32 1/3 art. (137)

$17 \mathrm{~T} . / \mathrm{w}$ (169) (in fall, 315)

5 T./b (171) (in fall, 315)

992 den./c (196) (in 316)

34 5/12 art. (181)

33 art. (206)
N. B.: $w=$ wheat
$\mathrm{b}=$ barley
$c=$ chatf

54 art. (204)

$317 / 318$
(ind. 6)

318/319

(ind. 7)

54 art. (215)

33 art. (217)

$319 / 320$

(ind. 8)

40 art. (226)

$320 / 321$

(ind. 9)

321/322

(ind. 10)

$322 / 323$

- (ind. 11)

$323 / 324$

(ind. 12)

5(4?) art. (234)

33 art. (244)

14 art. (245)

4(0?) art. (254)

$591 / 6$ art. (262,

22 art. (264)

$263,270)(6 \mathrm{for}$

aporoi, 6 for

epibole) 
Diatyposis

Others

1 T. 3000 dr. (14)

(in 312)

4000 dr. (18)

1 T. 700 dr. (24)

(for 19-7-5 and

1 T. 1760 dr. (64)

8-6-4 = 310/1

(for Philad.)

$4120 \mathrm{dr}$. (65)

and 311/2)

(for Tanis)

(both paid in 313)

2 T. (33) (when?)

2 T. (50)

1 T. 5960 dr. (82)

(paid in 312)

(in 314)

$\begin{array}{ll}1 \mathrm{~T} .2000 \mathrm{dr} .(55) & 3324 \mathrm{dr} .(67) \\ 3500 \mathrm{dr} .(58) & 1332 \mathrm{dr} \text { ( } 68) \\ & \text { (paid in advance) }\end{array}$

total of

2 T. (123)

5000 dr. (129)

2 T. $1000 \mathrm{dr}$.

(154-162)

2 T. 3000 dr.to- 5000 dr. (118)

tal (108-114); (paid in advance)

$1000 \mathrm{dr}$. in 1 art.

barley

5000 dr. (124)

(paid in 314/5)

800 dr. (126)

(asbestos)

not delivered would have been necessary. The other payments in cash are similarly missing after 314/5, and none of them has an unbroken sequence of payments in earlier years.

- The conclusion is inescapable that Thaeis and Harpokration had at least one other document containing tax receipts, prineipally for money taxes. They may have had smaller receipts for individual payments, never recopied and summarized on the tax roll, or they may have had one or more additional rolls. It therefore seems to us difficult to make any coherent argument about the level of the money taxes, even in the years for which there are payments, though the payments for primipilon and diatyposis may well be complete for those years for which they are preserved.

For wheat and barley, however, it seems more possible to think that our figures are complete. For one thing, a delivery of as much as 75 or 93 artabas of wheat at one time is hardly likely, and the receipt on the roll must therefore represent the summation of smaller individual deliveries over the course of the harvest period. In all likelihood, since we in no case have a second such receipt for a given harvest, the 
taxpayers waited until they had completed all anticipated deliveries in kind before having this receipt composed. After that, deficiencies were made up in cash. Adaeratio for wheat is negligible in $311 / 2$ and nil in 312/3, but after that it becomes important in 314/5, and as is shown below, the adaeratio in that year allows us to estimate a total payment close to the level of wheat paid in $311 / 2$ and 312/3. Similar ealculations are possible also for barley. For the size of the estate indicated by these tax payments, see below.

\section{The Taxpayers}

All of the payments in this roll are made in the names of Thaeis, daughter of Sarbas (a name not attested elsewhere), and Harpokration the veteran. Kase expressed doubt about their capacity as payers and their relationship with each other, remarking

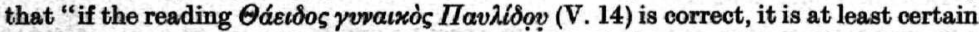
that Harpokration and Thaeis were not man and wife" (p. 2). The reading, however,

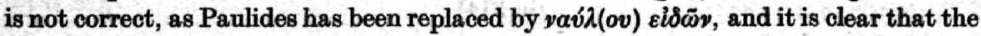
phrase indeed means "Thaeis his wife". There is therefore no reason not to think that we have payments for the joint account of the couple, though that need not mean that they owned land in common as opposed to separately.

Harpokration was dead by 321, when the taxes were paid for the account of Thaeis and the heirs of Harpokration (233). In the following year the phrasing, with $\delta$ id

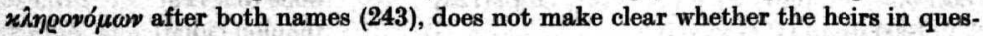
tion are those of both or only Harpokration; and in 323 the text is too heavily restored to allow inference (253). In the last receipt, in 324 , the two are referred to without any mention of heirs, suggesting that both were alive (258). The more likely supposition is that Thaeis was still alive in 324 paying on behalf of the estate of Harpokration.

A rough estimate of the size of the estate held by the couple may be essayed on the basis of their tax payments. We cannot, of course, be certain that we have the complete tax payments in any given year, but we find a certain consistency: in $311 / 2$ and $312 / 3$, they paid about 93 art. of wheat; and in $314 / 5$, the adaeratio for wheat would, converted into artabas at 2 artabas per talent, yield a total payment equivalent to about 88 art. (It should be pointed out that the equivalency 1 art. $=3000 \mathrm{dr}$. is vouched for in just this year by line 157). For barley, similarly, we find a total of 71 1/2 in 310/311, which falls off to $531 / 3$ the next year. But adaeratio of 2 T. 4,460 dr. for barley should equal at least 16 artabas and probably a bit more (an equivalency of 1,000 dr./art. appears in line 114 in 315/6), giving a total over 69.

If one applies to these figures the methods and formulas developed from the Isidoros papyri (see Cd'E 52 [1977] 322-336), one may estimate that the couple owned a total of about 81 arouras, with somewhat more than half of them in "public" land. This figure is rather reminiscent of Isidoros' holdings at a certain point in his life, and establishes Harpokration and Thaeis as among the more important residents of their village. We have, unfortunately, no other papers from their archives, but we may well imagine that if we did, we would find many of the kinds of transactions which occur in the Isidoros archive.

\section{The Officials of Philadelphia}

The many receipts contained in this roll give us an unusual opportunity to assemble parts of the roster of liturgical officials of the village of Philadelphia over the period 
of a bit more than a decade. The fact set out above in the table of tax payments, that only for wheat and barley does the roll continue beyond the first few years that it covers, means that only for sitologoi is our list even somewhat complete; for the rest we have bits and pieces. The known liturgists are set out below in tabular form.

\section{Sitologoi}

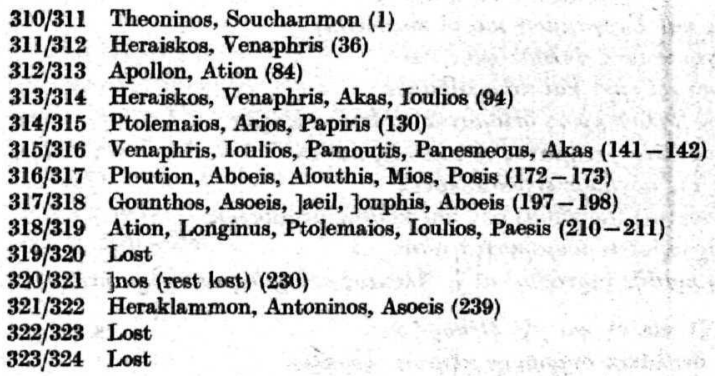

\section{A paitetai}

$311 / 312$ Jo(n), Neilammon (bouleutes, presumably apaitetes) (25)

312/313 Dioskorion (26, ef. 34-35)

315/316 Posis, Paesis (105)

\section{Onelatai}

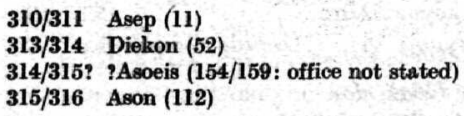

\section{Kephalaiotai}

312/313 Arianos, Apollon, Posis, Aion (komarchs and kephalaiotai) (47)

314/315 Pasis, Paesios (153, 155, 160)

315/316 Pasis, Paesios (112-113)

\section{Komarchs}

312/313 Arianos, Apollon (?: cf. under kephalaiotai) (47)

314/315 Gounthos (158)

Because we are dealing with a tax roll belonging to a taxpayer and not with any official papers of the liturgists involved, we have nothing more than the bare names for these office-holders. We lack, in particular, any patronymics which would help us to be certain about the identity of homonyms. It seems to us at least likely that in a small village with a presumably limited supply of propertied liturgists homonyms are in fact likely to be the same person. Such a supposition obviously cannot be demonstrated. If it is true, we find that Venaphris was sitologos in alternating years three times; Heraiskos served twice with a year in between; Ioulios three times in six years; and several others twice in the period covered. Gounthos was sitologos in 
317/8, three years after his term as komarch. The other possible identifications of officials are the following:

Paesis: sitologos 318/9, apaitetes, 315/6, kephalaiotes 314/5, 315/6

Asoeis: sitologos 317/8, 321/2; onelates 314/5

\section{Column I}

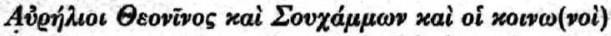

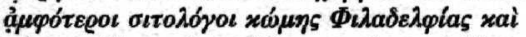

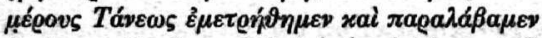

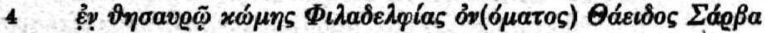

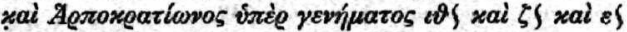

$310 / 1$

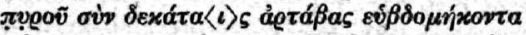

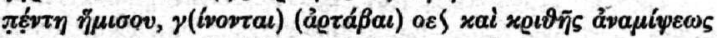

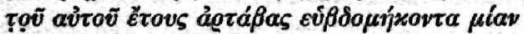

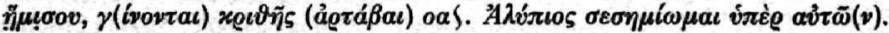

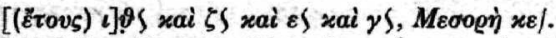

18. viii. 311

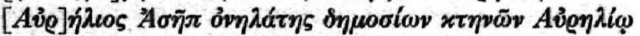

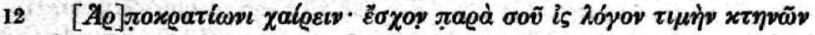

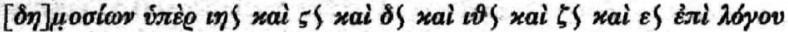

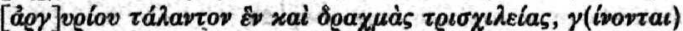

309/310, $310 / 1$

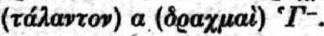

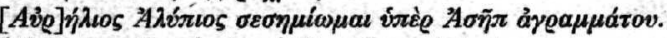

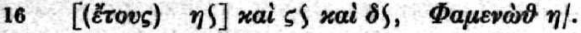

4.iii. 312

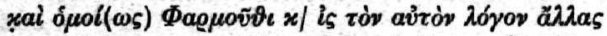

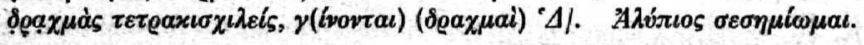

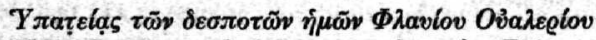

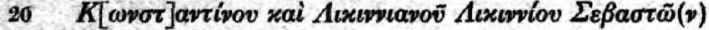

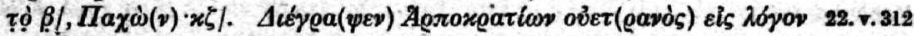

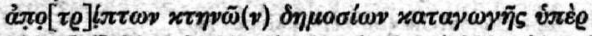

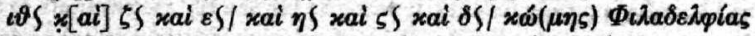

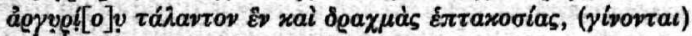

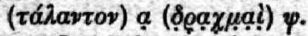

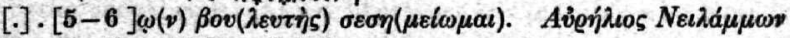

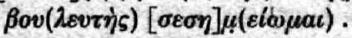

\section{Column I, Right Margin}

xai \&c'époũ Aloorogíavas

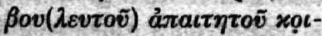

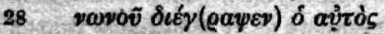

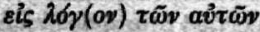

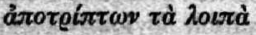

I oi pap. 18 retgaxí- pap. (trema smeared) $19 \eta \mu \omega \nu^{-}$, phaviov pap. $23 \eta\{: \eta$ ex 5

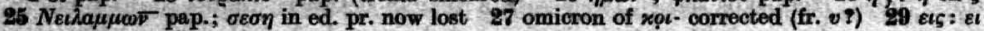
rewritten over a first try 
Posis: sitologos 316/7, apaitetes 315/6, kephalaiotes 312/3? (cf. 105n.)

Apollon: komarch 312/3, sitologos 312/3

In general, we find a rather small circle of men carrying these posts from year to year.

\section{Note on Chronology}

The julian equivalents of exact dates, Egyptian fiscal years, and julian calendar years are given in the margin. These equivalences are based on the tables and discussions in our Chronological Systems of Byzantine Egypt (Zutphen 1978) (abbreviated $C S B E$ ) and our Regnal Formulas in Byzantine Egypt (Missoula 1979) (abbreviated $R F B E)$. Individual references are given in the line notes only in exceptional cases. For a general treatment of the subject the reader is referred to our article in GRBS 20 (1979) 279-295.

\section{Column-I}

We, Aurelii Theoninos and Souchammon and their partners, all sitologoi of the village of Philadelphia and the district of Tanis, have had measured and have received in the granary of the village of Philadelphia in the name of Thaeis daughter of Sarbas and Harpokration for the crop of the 19th and 7 th and 5th year, seventy-five and a half artabas of wheat including the tenths, total, $751 / 2$ art., and seventy-one and a half artabas of barley in exchange for the same year, total 71 1/2 art. barley. I, Alypios, have signed on their behalf. [Year 1]9 and 7 and 5 and 3, Mesore 25.

Aurelios Asep, donkey-driver of public donkeys, to AureliusHarpokration greetings. I have received from you on account of the value of public donkeys for the 18th and 6th and 4th and the 19th and 7 th and 5th years on account, one talent and three thousand drachmas of silver, total, 1 T., 3,000 dr. I, Aurelius Alypios, have signed for Asep who is illiterate. [Year 8] and 6 and 4, Phamenoth 8.

And likewise on Pharmouthi 20 on the same account, a further four thousand drachmas, total 4,000 dr. I, Alypios, have signed.

In the consulate for the 2nd time of our masters Flavius Valerius Constantinus and Licinnianus Iicinnius Augusti, Pachon 27. Harpokration the veteran has paid on account of worn out public donkeys for transport for the 19th and 7th and 5th and the 8 th and 6 th and 4 th years for the village of Philadelphia one talent and seven hundred drachmas of silver, total, 1 T. $700 \mathrm{dr}$. [I, ...-]on, councillor, have signed. I, Aurelius Neilammon, councillor, have signed.

\section{Column I, Right Margin}

And through me, Dioskorion, councillor, collector, (their) partner, the same man has paid on account of the same worn-out (donkeys) the current balance 


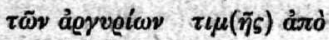

xaS/I àvà $\chi \varepsilon i \varrho a$

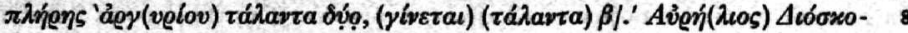

\section{Column II}

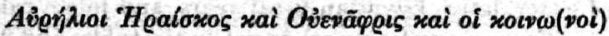

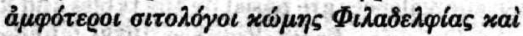

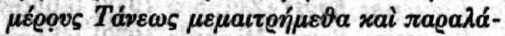

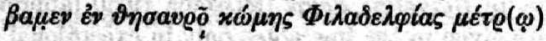

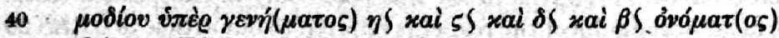

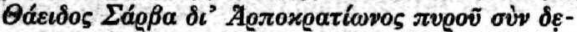

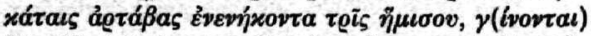

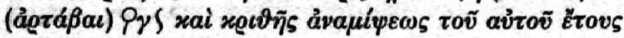

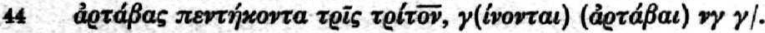

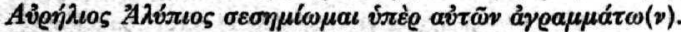

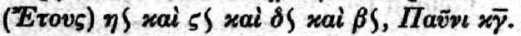

17. vi. 312

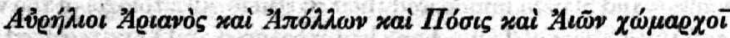

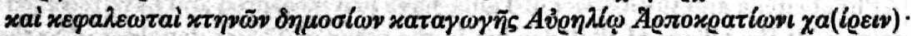

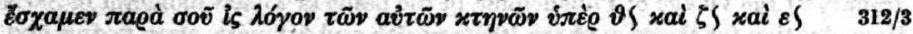

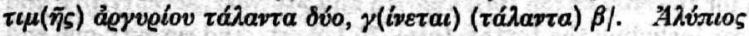

$\sigma \varepsilon \sigma \eta \mu l \omega \mu a t$.

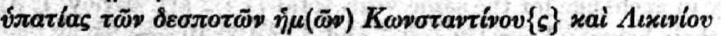

$\sum \varepsilon \beta a \sigma \tau \tilde{\omega} v \tau \dot{\partial} \beta \mid$.

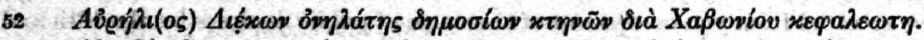

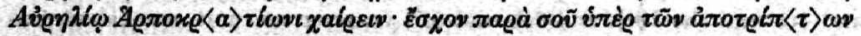

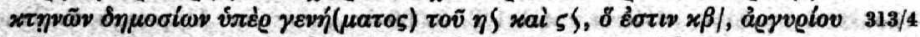

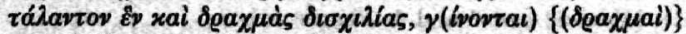

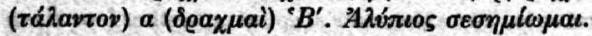

56 ('Ezovs) $\eta S$ rai 5 S, Exip 15.

10. vii. 314

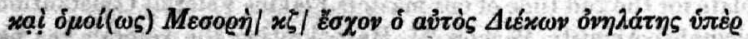

20. viii. (314) $\tau \tilde{\omega} \boldsymbol{\alpha} \alpha \boldsymbol{\tau} \tilde{\omega}(\boldsymbol{v})$

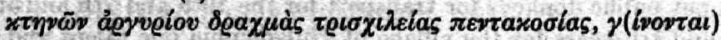

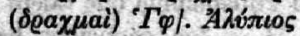

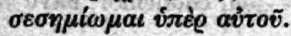

\section{Column III}

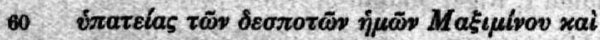

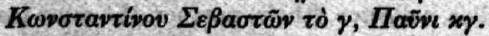

17. vi. $\mathbf{3 1 3}$

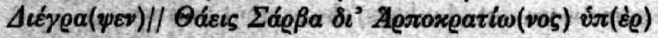

35 -

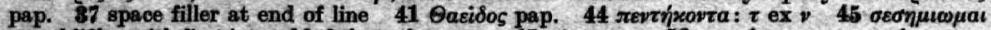

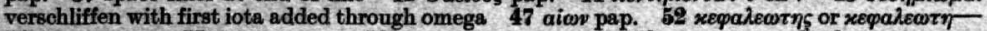

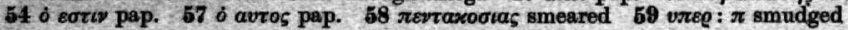


of the money for their value from the 2lst year in full, two talents of silver, total, 2 T. I, Aurelius Dioskoros, councillor, have signed.

\section{Column II}

We, Aurelii Heraiskos and Venaphris and their partners, all sitologoi of the village of Philadelphia and the district of Tanis, have had measured and have received in the granary of the village of Philadelphia by the modius measure for the crop of the 8th and 6th and 4th and 2nd year in the name of Thaeis daughter of Sarbas, through Harpokration, ninety-three and a half artabas of wheat including the tenths, total, $931 / 2$ art., and fifty-three and a third artabas of barley in exchange, for the same year, total, $531 / 3$ art. I, Aurelius Alypios, have signed for them since they are illiterate. Year 8 and 6 and 4 and 2, Pauni 23.

Aurelii Arianos and Apollon and Posis and Aion, komarchs and kephalaiotai of public donkeys for transport, to Aurelius Harpokration, greetings. We have received from you on account of the same donkeys for the 9 th and 7 th and 5 th year, for value two talents of silver, total, 2 T. I, Alypios, have signed. In the consulate of our masters Constantine and Licinius Augusti for the 2nd time.

Aurelius Diekon, donkey-driver of public donkeys, through Chabonius the kephalaiotes, to Aurelius Harpokration greetings. I have received from you for the wornout public donkeys for the crop of the 8th and 6th year, which is the 22nd, one talent of silver and two thousand drachmas, total, 1 T., 2000 dr. I, Alypios, have signed. Year 8 and 6, Epeiph 16.

And likewise, Mesore 27, I, the same Diekon, donkey-driver, have received for the same donkeys, three thousand five hundred drachmas of silver, total, 3,500 dr. I, Alypios, have signed on his behalf.

\section{Column III}

In the consulate of our masters Maximinus and Constantine Augusti for the 3rd time, Panni 23. Thaeis daughter of Sarbas has paid through Harpokration for 


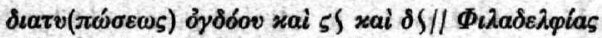

64

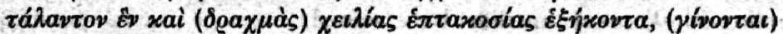

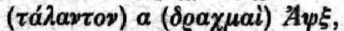

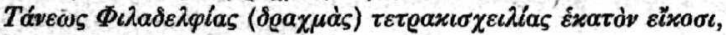

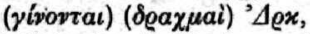

xai

$\delta$ É $\sigma \tau \imath$ x $x \beta S /$,

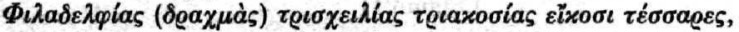

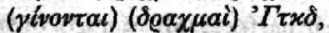

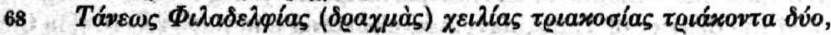

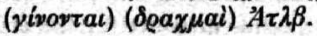

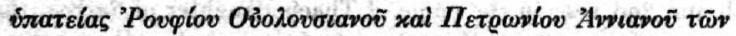

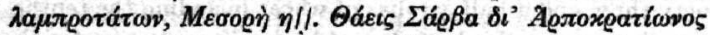

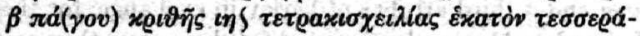

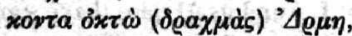

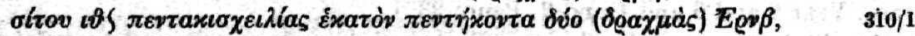

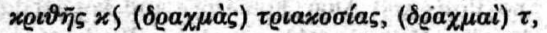

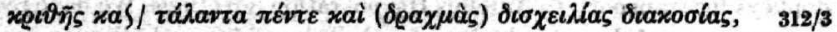

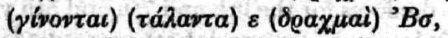

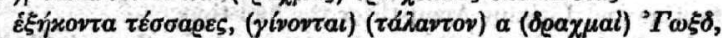

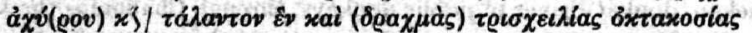

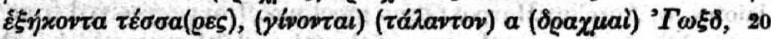

80

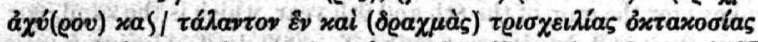

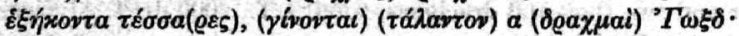

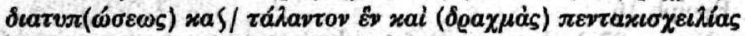

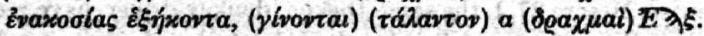

\section{Column IV}

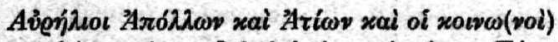

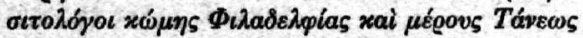

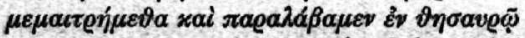

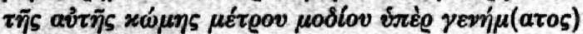

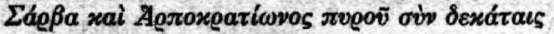

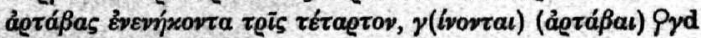

xai xอเขีที

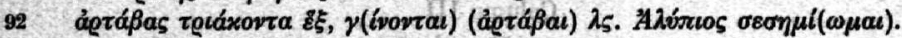

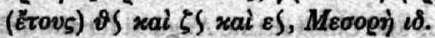

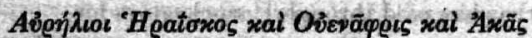

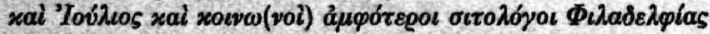

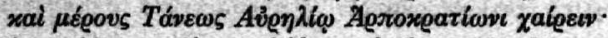

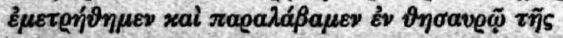

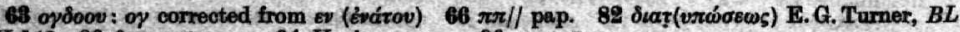

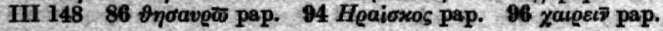


delegatio of the eighth and 6th and 4th year for Philadelphia, one talent and one thousand seven hundred sixty dr., total, 1 T. 1,760 dr.; for Tanis (dependency of) Philadelphia, four thousand one hundred twenty dr., total, 4,120 dr.; and for primipilon of the fortunately approaching 10th and 8th year, which is the 22nd, for Philadelphia three thousand three hundred twenty-four dr., total, 3,324 dr.; for Tanis (dependency of) Philadelphia, one thousand three hundred thirty-two dr., total, $1,332 \mathrm{dr}$.

In the consulate of Rufius Volusianus and Petronius Annianus the most illustrious, Mesore 8. Thaeis daughter of Sarbas (has paid) through Harpokration for the 2nd pagus for barley of the 18th year, four thousand one hundred forty-eight, dr. 4,148; for wheat of the 19th year, five thousand one hundred fifty-two, dr. 5,152; for barley of the 20th year, three hundred dr., dr. 300; for barley of the 21st year, five talents and two thousand two hundred dr., total, 5 T. 2,200 dr.; for chaff of the 19th year, one talent and three thousand eight hundred sixty-four dr., total, 1 T., 3,864 dr.; for chaff of the 20th year, one talent and three thousand eight hundred sixty-four dr., total, 1 T., 3,864 dr.; for chaff of the 2lst year, one talent and three thousand eight hundred sixty-four drachmas, total, 1 T. 3,864 dr. For delegatio of the 21st year, one talent and five thousand nine hundred sixty dr., total, 1 T. 5,960 dr.

\section{Column IV}

We, Aurelii Apollon and Ation and their partners, sitologoi of the village of Philadelphia and district of Tanis, have had measured out and have received in the granary of the same village, by the modius measure, for the crop of the 21st year, which is the 9th and 7th and 5th, in the name of Thaeis daughter of Sarbas and of Harpokration, ninety-three and a quarter artabas of wheat, including the tenths, total, art. $931 / 4$, and thirty-six artabas of barley in exchange, for the same year, total, art. 36. I, Alypios, have signed. Year 9 and 7 and 5, Mesore 14.

Aurelii Heraiskos and Venaphris and Akas and Iulius and their partners, all sitologoi of Philadelphia and the district Tanis to Aurelius Harpokration, greetings. We have had measured and have received in the granary of the 


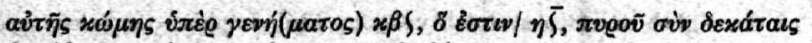

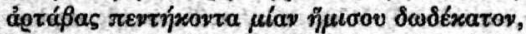

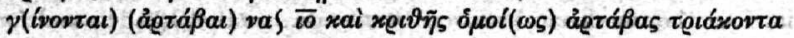

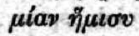

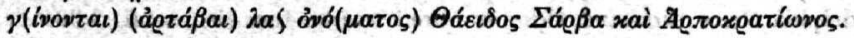

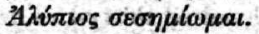

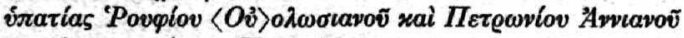

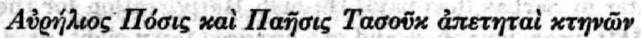

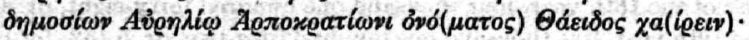

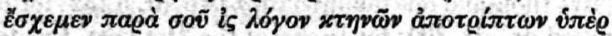

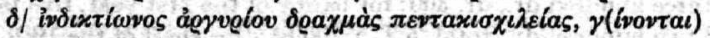

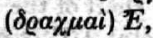

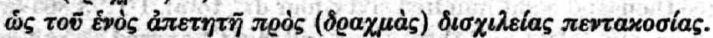

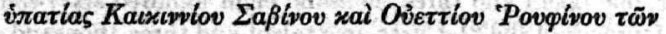

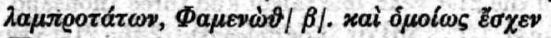

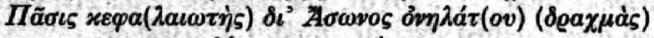

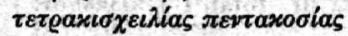

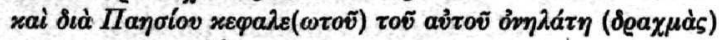

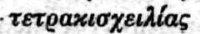

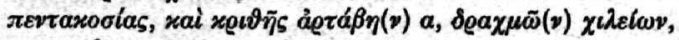

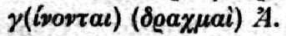

\section{Column V}

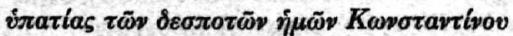

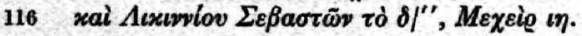

12. ii. 315

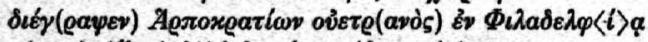

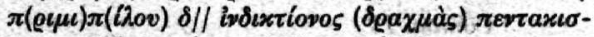

$315 / 64$

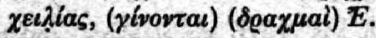

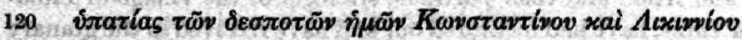

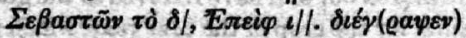

4. vii. 315

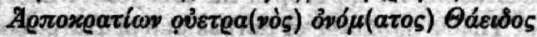

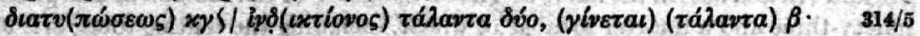

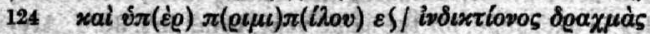

$316 / 7$

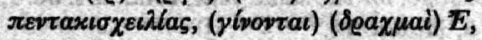

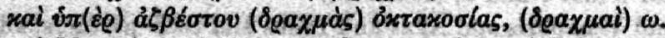

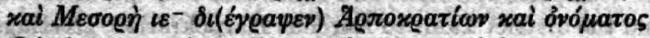

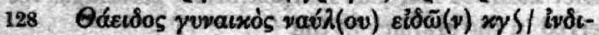

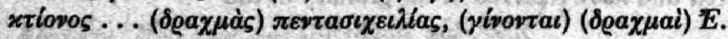

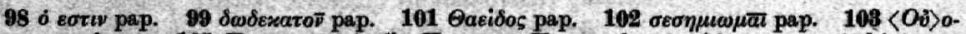

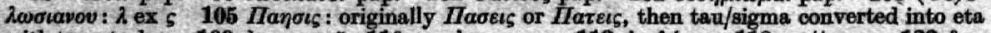

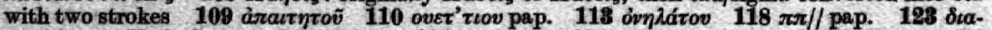

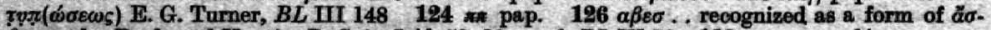

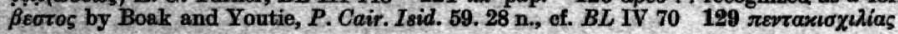


same village for the orop of the $22 \mathrm{nd}$ year, which is the 8 th, fifty-one, a half, a twelfth artabas of wheat, including the tenths, total, art. 51 1/2 1/12, and of barley likewise, thirty-one and a half artabas, total, art. 31 1/2 in the name of Thaeis daughter of Sarbas and of Harpokration. I, Alypios, have signed. In the consulate of Rufius Volusianus and Petronius Annianus the most illustrious, Pauni 30.

Aurelius Posis and Paesis son of Tasouk, collectors for public donkeys, to Aurelius Harpokration, in the name of Thaeis, greeting. We have received from you on account of worn-out donkeys for the 4 th indiction five thousand drachmas of silver, total, $5,000 \mathrm{dr}$., at two thousand five hundred $\mathrm{dr}$. for each collector. In the consulate of Caecinius Sabinus and Vettius Rufinus the most illustrious, Phamenoth 2. And likewise Pasis the kephalaiotes has received. through Ason the donkey-driver four thousand five hundred dr., and through Paesios the kephalaiotes (through) the same donkey-driver, four thousand five hundred dr., and 1 artaba of barley for a thousand drachmas, total, $1,000 \mathrm{dr}$.

\section{Column V}

In the consulate of our masters Constantinus and Licinnius Augusti for the 4th time, Mecheir 18. Harpokration, veteran, has paid in Philadelphia for primipilon of the 4th indiction five thousand $\mathrm{dr}$., total, $5,000 \mathrm{dr}$.

In the consulate of our masters Constantinus and Licinnius for the 4th time, Epeiph 10. Harpokration, veteran, has paid in the name of Thaeis for delegatio of the 23rd indiction two talents, total, 2 T. And for primipilon of the 5 th indiction, five thousand drachmas, total, 5,000 dr, And for unslaked lime eight hundred dr., total, $800 \mathrm{dr}$. And Mesore 15 Harpokration paid, also in the name of Thaeis his wife, transportation charges on goods for the $23 \mathrm{rd}$ indiction ... five thousand $\mathrm{dr}$., total, $5,000 \mathrm{dr}$. 


\section{Column VI}

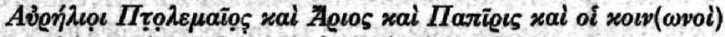

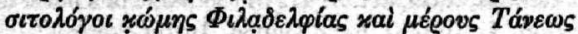

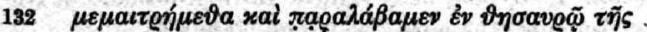

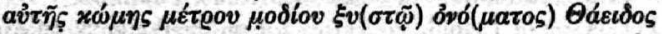

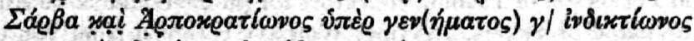
สขอоขี

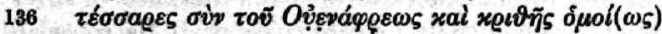

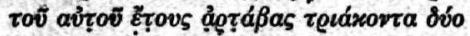

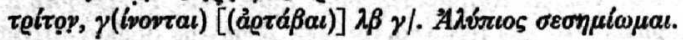

\section{$2.5 \mathrm{~cm}$. space blank}

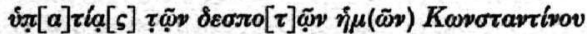

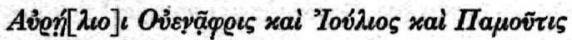

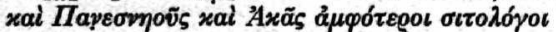

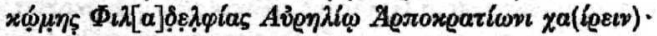

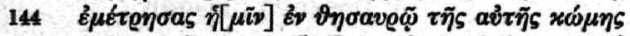

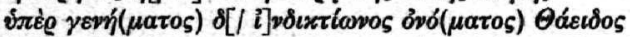

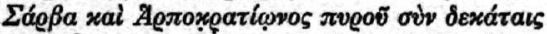

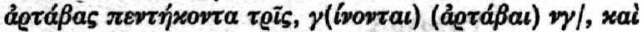

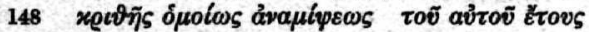

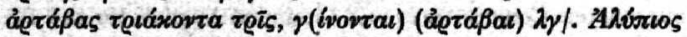

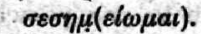

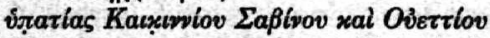

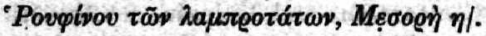

\section{Column VII}

152

$$
\text { ] } \ldots \gamma \gamma / \text { i... } \delta[[x] \tau\{\omega \text { pos }
$$

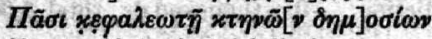

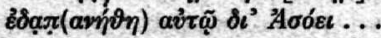

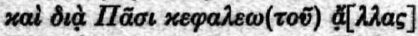

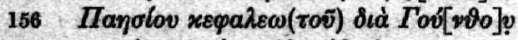

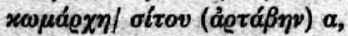

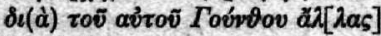

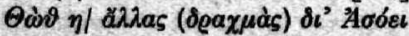

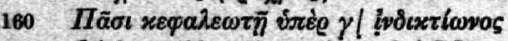

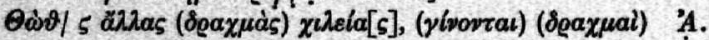

$\triangle \varphi \varphi /$.

A $|\varphi|$.

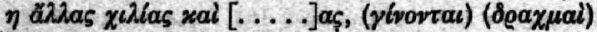

' $T$.

A.

$\Delta \varphi$.

6. ix. (315) / IIaEлıs nal A . o.![.]. oux

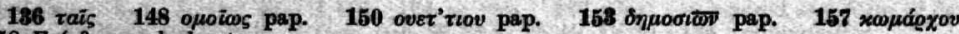
158 Toúvolov washed out 


\section{Column VI}

We, Aurelii Ptolemaios and Arios and Papiris and our partners, sitologoi of the village of Philadelphia and district of Tanis, have had measured and have received in the granary of the same village, by the level modius measure, in the name of Thaeis daughter of Sarbas and of Harpokration, for the crop of the 3rd indiction, fifty-four artabas of wheat, including the tenths, including those of Venaphris, and likewise thirtytwo and a third artabas of barley for the same year, total, 32 1/3 [art.] I, Alypios, have signed.

In the consulate of our masters Constantinus and Licinnius Augusti for the 4th time, Mesore 3.

Aurelii Venaphris and Iulius and Pamoutis and Panesneous and Akas, all sitologoi of the village of Philadelphia, to Aurelius Harpokration, greetings. You measured to us in the granary of the same village for the crop of the 4th indiction in the name of Thaeis daughter of Sarbas and of Harpokration, fifty-three artabas of wheat, including the tenths, total, 53 art., and likewise thirty-three artabas of barley in exchange, for the same year, total, 33 art. I, Alypios, have signed.

In the consulate of Caecinius Sabinus and Vettius Rufinus the most illustrious, Mesore 8.

\section{Column VII}

$\ldots$ 3rd indiction.

To Pasis, kephalaiotes of public donkeys, there was expended to him through Asoeis

And through Pasis, kephalaiotes, another

dr. 4,500

dr. 1,500

To Paesios, kephalaiotes, through Gounthos the komaroh,

one art. of wheat,

dr. $\mathbf{3 , 0 0 0}$

Through the same Gounthos, another

dr. 1,500

Thoth 8, through Asoeis, another

dr. 4,600

To Pasis, kephalaiotes, for the 3rd indiction,

Thoth 6, another dr. one thousand, total,

dr. 1,000

The 8th, another thousand and ..., total,

dr. 2,000

Paepis and ... 


\section{Column VIII}

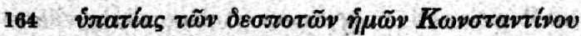

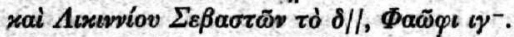

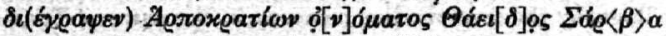


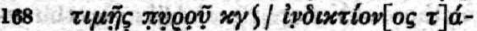

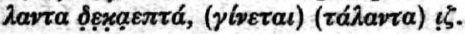

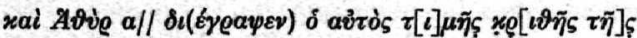

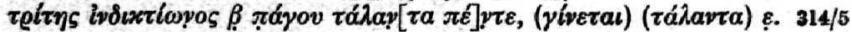

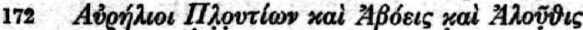

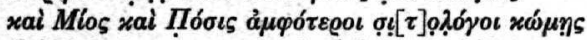

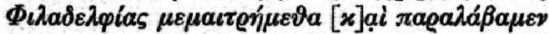

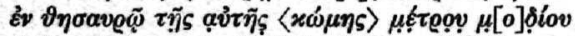

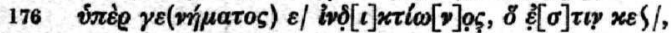

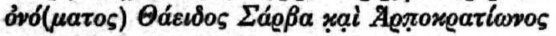

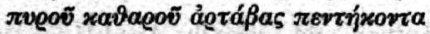

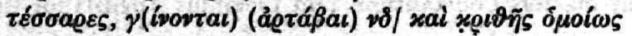

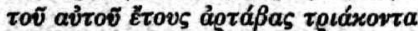

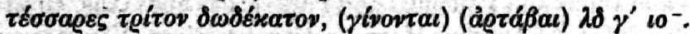

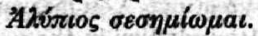

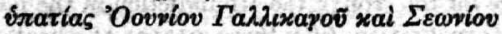

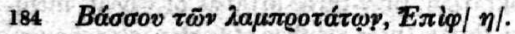

\section{Column IX}

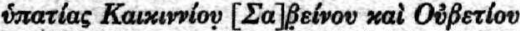

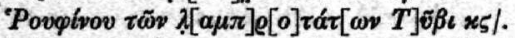

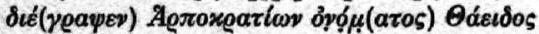

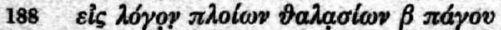

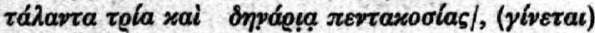

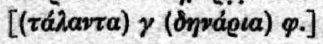

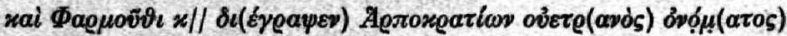

15.iv, (316)

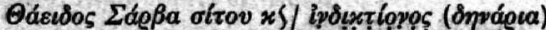

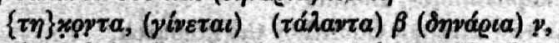

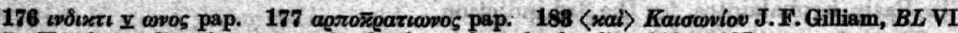
117; Kase's reading is correct; for haplography ef. also line 103 187 agroxeagricon pap.

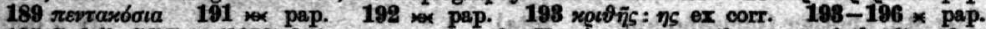
195 Cadell, $C d^{\prime} E 48$ (1973) 354 proposes ofrov for Kase's swepp at the start of the line, but neither reading seems possible. 


\section{Column VIII}

In the consulate of our masters Constantinus and Licinius Augusti for the 4th time, Phaophi 13. Harpokration has paid in the name of Thaeis daughter of Sarbas for the village of Philadelphia and district of Tanis, for the value of wheat for the 23rd indiction, seventeen talents, total, $17 \mathrm{~T}$.

And Hathyr 1, the same man paid for the value of barley for the third indiction for the 2nd pagus, five talents, total, $5 \mathrm{~T}$.

We, Aurelii Ploution and Aboeis and Alouthis and Mios and Posis, all sitologoi of the village of Philadelphia, have had measured and have received in the granary of the same (village) by the modius measure, for the crop of the 5th indiotion, which is the 25th, in the name of Thaeis danghter of Sarbas and of Harpokration, fifty-four artabas of clean wheat, total, art. 54, and likewise of barley for the same year thirtyfour, a third, a twelfth artabas, total, art. 34 1/3 1/12. I, Alypios, have signed. In the consulate of Ovinius Gallicanus and Caesonius Bassus the most illustrious, Fpeiph 8.

\section{Column IX}

In the consulate of Caecinius Sabinus and Vettius Rufinus the most illustrious, Tybi 26. Harpokration has paid in the name of Thaeis for the account of seagoing ships for the 2nd pagus three talents and five hundred denarii, total, [3 T., 500 den.]

Pharmouthi 20, Harpokration, veteran, paid in the name of Thaeis daughter of Sarbas for grain for the 20 th indiotion, one hundred ninety-three denarii, 193 den. For barley for the 20th, two talents and fifty den., total, 2 T., 50 den., and for the 20 th year, nine hundred ninety den., total, 990 den. For chaff for the 23rd year, nine hundred ninety-two den. 


\section{Column $\mathbf{X}$}

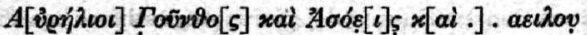

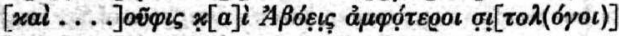

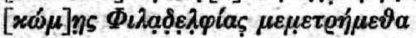

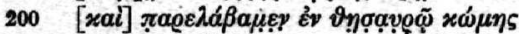

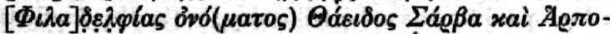

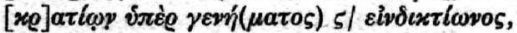

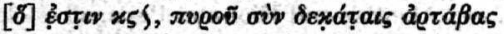

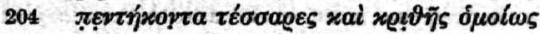

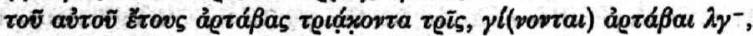

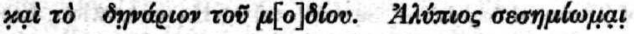

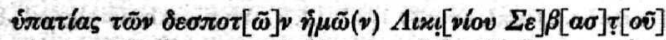

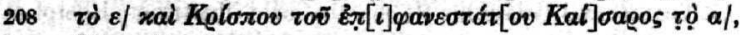

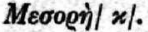

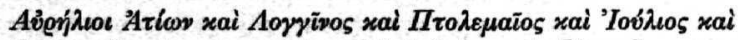

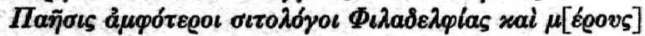

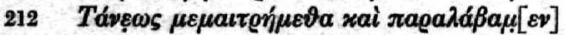

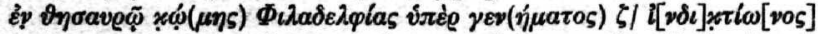

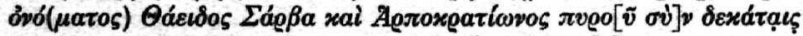

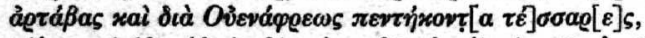

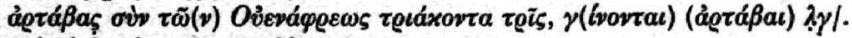

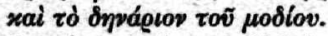

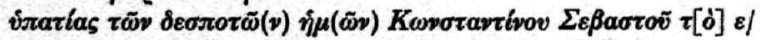

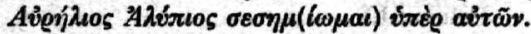

\section{Column XI}

[Av้é̉ xai of $\operatorname{xotv}(\omega v o i)]$

[ả

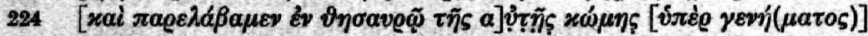

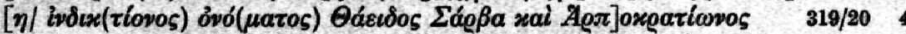

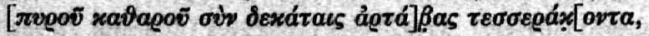

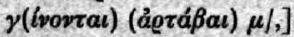

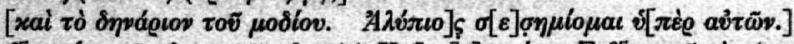

$228 v[\pi \alpha \tau i a \varsigma$ र

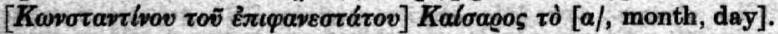




\section{Column X}

We, Aurelii Gounthos and Asoeis and ... aeilos and . . . ouphis and Aboeis, all sitologoi of the village of Philadelphia, have had measured [and] have received in the granary of the village of Philadelphia in the name of Thaeis daughter of Sarbas and of Harpokration for the crop of the 6th indiction, which is the 26th, fifty-four artabas of wheat, including the tenths, and thirty-three artabas, likewise, of barley for the same year, total, art. 33, and the denarius per modius. I, Alypius, have signed.

In the consulate of our masters Licinius Augustus for the 5th time and Crispus the most noble Caesar for the Ist, Mesore 20.

We, Aurelii Ation and Longinus and Ptolemaios and Iulius and Paesis, all sitologoi of Philadelphia and the district of Tanis, have had measured and have received in the granary of the village of Philadelphia for the crop of the 7 th indiction in the name of Thaeis daughter of Sarbas and of Harpokration, fifty-four artabas of wheat, including the tenths, including also those paid through Venaphris, total, art. 54, and likewise thirty-three artabas of barley for the same year [of the] 7th indiction, including those paid through Venaphris, total, art. 33, and the denarius per modius.

In the consulate of our masters Constantinus Augustus for the 5th time and Lieinius the most noble Caesar for the 1st, Epeiph . . . I, Aurelius Alypios, have signed on their behalf.

\section{Column XI}

[We, Aurelii . . . and partners, all sitologoi of the village] of Philadelphia, have had measured [and have received in the granary of the] same village [for the crop of the 8th indiction, in the name of Thaeis daughter of Sarbas and] of Harpokration, forty artabas [of clean wheat, including the tenths, total, art. 40, and the denarius per modius. I, Alypios, ] have signed for [them]. In the consulate [of our masters] Constantinus Angustus [for the 6th time and Constantinus the most noble] Caesar for the [1st time...] 


\section{Column XII}

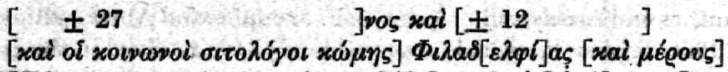

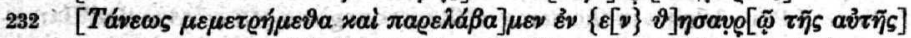

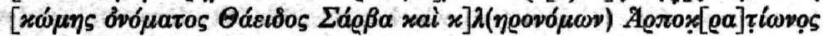
[ovetอavoṽ]

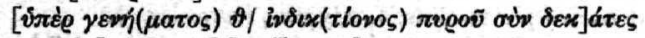

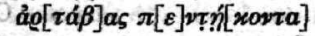

$\left[\right.$ ].(.) [] . viż. []$^{-}$

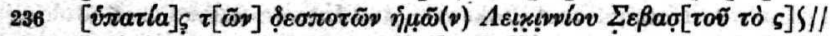

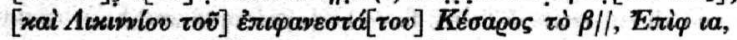

5. vii. 3218

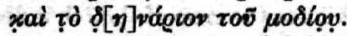

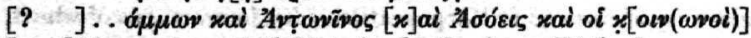

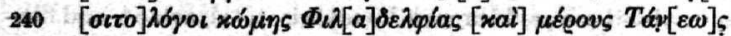

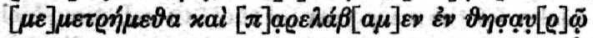

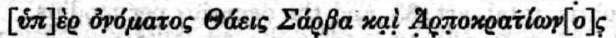

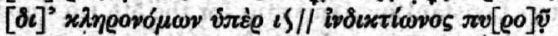

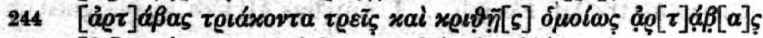

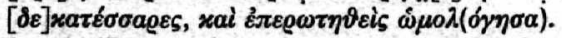

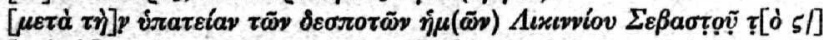

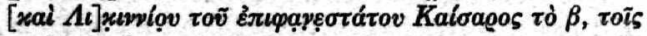

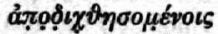

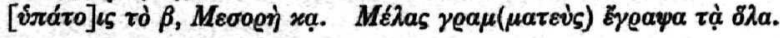

\section{Column XIII}

[ xai of xoiv( $\omega v 0 i)]$

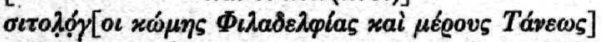

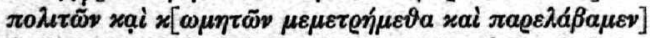

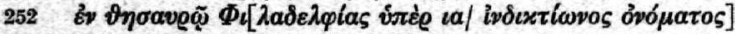

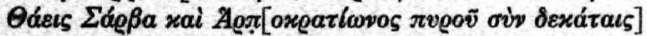

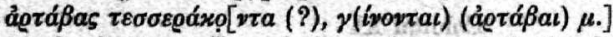

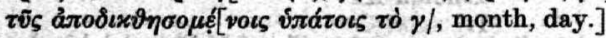

Column XIV

256

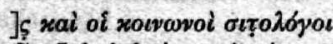

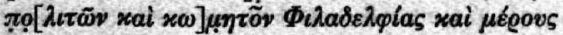

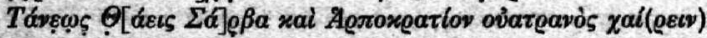

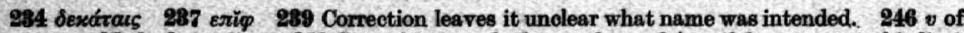
virarelav added above line 253 Something washed out above Qdess (false start on this line) 255 roīs 258 oviergavós, read oviergavọ 


\section{Column XII}

... [and partners, sitologoi of the village] of Philadelphia [and district of Tanis, have had measured and] have received in the granary [of the same village, in the name of Thaeis daughter of Sarbas and] the heirs of Harpokration [the veteran, for the crop of the 9th indiction], fifty artabas [of wheat, including] the tenths, ... In the consulate of our masters Licinius Augustus [for the 6th time and Licinius the] most noble Caesar for the 2nd time, Epeiph 11, and the denarius per modius.

[We, Aurelii (?) -..-] ammon and Antoninus and Asoeis and partners, sitologoi of . the village of Philadelphia [and] the district of Tanis, have had measured and have received in the granary for the name of Thaeis daughter of Sarbas and of Harpokration, through his heirs, for the 10th indiction, thirty-three artabas of wheat and likewise fourteen artabas of barley, and having been asked the formal question, I assented. After the consulate of our lords Licinius Augustus for the [6th time and] Licinius the most noble Caesar for the 2nd time, under the consuls yet to be designated for the 2nd time, Mesore 21. I, Melas, scribe, wrote the entirety.

\section{Column XIII}

[We, ... and partners], sitologoi [of the village of Philadelphia and dictrict of Tanis] for eitizens and villagers], have had measured and have received] in the granary of Philadelphia [for the 11th indiction in the name of] Thaeis daughter of Sarbas and of Harpokration, forty (?) artabas [of wheat, including the tenths, total, 40 art.] Under the [eonsuls] to be designated [for the 3rd time,.... ]

\section{Column XIV}

[-.-] and partners, sitologoi for citizens and villagers of Philadelphia and the district of Tanis, to Thaeis daughter of Sarbas and Harpokration, veteran, greetings. 


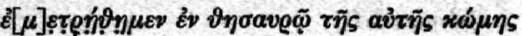

260

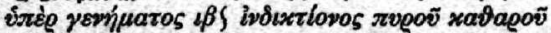

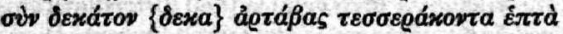

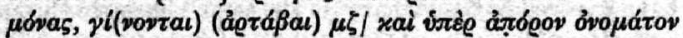

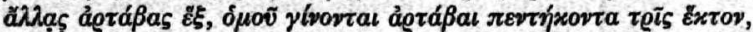

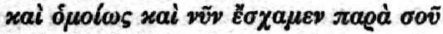

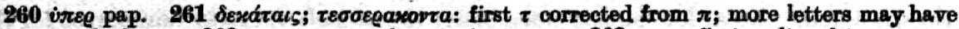

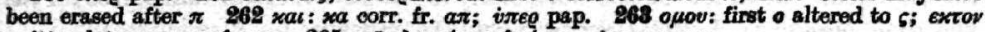

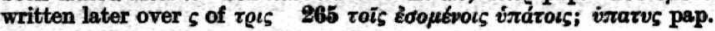

1-2 For the sitologoi in the fourth century, gee genally J. Lallemand, L'administration civile, 207-210, and of. R. S. Bagnall and K. A. Worp, BASP 18 (1981) 38-44. For the sitologoi occurring in this tax roll of. supra, p. 59. For the use of dupórego meaning more than two members of a college of officials, see Kase in P. Princ. Roll and Bagnall, Aegyptus 58 (1978) 160-167.

2-3 For Tanis as a dependency of Philadelphia see Kase's remarks in the ed. pr. P. Mich. inv. 1352, cited by him there, has been published as SB XII 10982. For the similar situation with Karanis and its surrounding hamlets, see P. Cair. Isid. 5, 6 introd., and 77. 17n.

5 et alibi We do not follow Kase's note in the ed. pr. (10n.) in the matter of interpreting the sinusoidal curves in the text (and in other papyri of this period); see our remarks in CSBE 2.

6 For the "tenth" see P. Cair. Ioid. 45. 7n. with references. For the spelling evipdoptýrovra see F. T. Gignac, Grammar I 70, II 197-198.

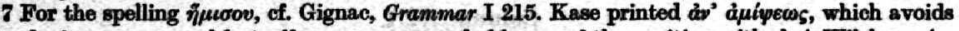
introducing a new word but offers a very remarkable use of the genitive with dvó. Wilaken, Archiv 11 (1935) $313 \mathrm{n}$. 3, proposed instead ávapeipews. In the similar context in P. Cair. Isid. 47. 44, we find duelpews ofrov with no preposition either separately or compounded, while in $\boldsymbol{P}$. Panop.

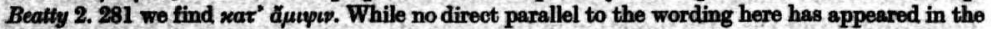
half century since the ed. pr., we have nevertheless adopted Wilcken's version. What "barley in exchange for wheat" means has not been made clear by other evidence so far published. We know that in the Ansinoite Nome rates were established in both wheat and barley; on the other hand, it seems that this was quite possibly not true in the Oxyrhynchite (see our remarks in ZPE 37 [1980] 263 - 264). We are far from knowing the functioning of the taxation system at any level [above the local, but it seems possible that the imperial government set a tax rate in wheat which was in some nomes partly converted into barley with official sanction. From the taxpayer's point of view, the tax in that case would be part wheat, part barley; but officials may have kept in mind the fact that the barley was in exchange for a part of the wheat. In this case, the phrases cited refer to an exchange at a higher level, not a taxpayer's ohoice to substitute one for the other.

11-18 J. Iallemand, L'administration eivile, 199, describes this kind of payment as "contribution au transport public par bêtes de somme, convertie." This view seems to indicate that she considers that people were obliged to furnish animals or the value of their services in cash. We are not confident that this is correct; the payment is for an assessment for the use (and replacement [cf. line 22 note]) of public animals for the transport of private grain (owed to the state as taxes), and we do not see why it should have been assessed in any form but money. Apart from the onelates

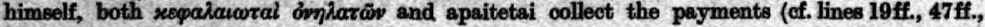
52ff., $105 \mathrm{ff}$., and 152fi.), and it is even possible that the same man may appear in both of the latter roles (cf. supra, p. 59 - 60). For transportation down to the Nile from Philadelphia, see P. Princ. II 26; of. P. Oair. Isid. 47. In., where Kerke is stated to be the end of the overland route.

12 rıp'v is superfluous, of. line $31 n$. 
We have had measured in the granary of the same village for the crop of the 12th indiction, forty-seven artabas only of clean wheat, including the tenths, total, art. 47, and on behalf of insolvent accounts, another six artabas, total altogether fiftythree and one-sixth artabas, and likewise twenty-two artabas only of barley for the same crop.

Under the consuls yet to be announced for the 4th time, Epeiph 5 , and the denarius. on these amounts.

And likewise even now we have received from you for the surcharge and ... of the same 12th indiction, six artabas of wheat including the tenths, total, art. 6. I, Melas, scribe, have signed.

22 Kase was uncomfortable with rendering arrorgirtwe as "worn out," but he was not much happier with his own suggestion of ajod Teırtwin. "Worn out" makes good sense, however, since one of the major costs to the state of maintaining this service would be the capital to replace animals when they were no longer good for service, and this cost must have been a part of the assessment to users of the publio animals. xarayrayr belongs, to be sure, to the preceding $x \pi \eta \eta \tilde{\omega}(v)$ inpooicin (cf. line 48) and does not denote an independent ground for the tax payment.

25 We should expect a change of hand between the two signatures in this line, but we cannot detect any. We suppose that these bouleutai held positions as apaitetai (cf. line 27). The bouleutes Neilammon appears also in P. Cair. Isid. 58. 18 (A. D. 315). If the other one is restored as Dioskorion (cf. line 26), there would hardly be space for Aurelius before his name, even abbreviated.

30 Cf. note on line 22.

$81 \tau \iota \mu(\tilde{\eta} s)$ seems superfluous; cf. line $12 \mathrm{n}$.

82 For dud $\chi \varepsilon i \varrho \varrho$, of. Preisigke, WB II 726. 31ff. As Kase remarked already in his note in the ed. pr., it is remarkable that this receipt is not dated by month and day; but the same thing happens in lines $47-51$. For the year, of. supra, p. 55.

34-35 Dioskoros is evidently the same as Dioskorion in line 26 ; such variation in a name is not uncommon.

89-40 For the modius measure see most recently J. C. Shelton, ZPE 42 (1981) 102-106.

41-42 The payment is presumably 85 art. plus $10 \%$; similar computations in the case of other payments mostly do not yield round figures; we do not know what degree of rounding was used by the collectors.

48 Cf. line $7 \mathrm{n}$.

47 The presence of four komarchs, while not unexampled, is uncommon; two were normal in Byzantine times, of. H. Missler, Der Komarch (Diss. Marburg/Lahn 1970) 15ff. We also do not expeot to find the same persons as komarchs and as kephalaiotai. The most likely explanation, we think, is that the first two names are those of the komarchs, the second two of the kephalaiotai. For Posis as kephalaiotes, of. 11-18 n., $105 \mathrm{n}$.

52 BL III 191 records the proposal of K. F. W. Schmidt to read Aváscevv here in place of the unattested name Diekon, but the editor's reading is preferable here and certain in line 57, and we have therefore not accepted Schmidt's proposal. Chabonios is also a hapax but similarly correctly read. One should either read xequilaw repaliaviri's, i. e. nom. for gen.

68 Acarv( $\left(\pi \omega \omega_{\varepsilon} \omega_{5}\right)$ : the reading was suggested by E. G. Turner, of. A. C. Johnson - L. C. West, Byzantine IFgypt (Princeton 1949) 219 n. 5 (missed by BL III 148, which picked up the same proposal elsewhere in the text). H. C. Youtie, Scriptiunculae II $951 \mathrm{n}$. 15, distinguishes three meanings of diatyposils; in BASP 15 (1978) 139, J. D. Thomas argues that Youtie's first and third meanings are the same thing, namely the tax schedule of a year, or delegatio. In the present instance, the 
parallelism of diatyposis to other specific taxes throughout the text suggests Youtie's category 2, i. e. a specific tax. We still understand the meaning of this term very imperfectly, in our judgment.

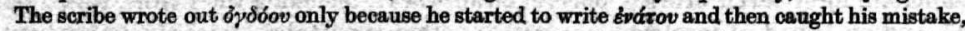
too late to use only numerals; for the writing out of "nine" and "ninth", see most recently J. D. Thomas, Chiron 10 (1980) 537-551.

66 For the tax named primipilon, see J.-M. Carrié, Actes XV Congr. Pap. IV, 156-176. The tax is-remarkably enough--paid in advance here, as also happens with the same tax in lines $115-118$ and 124, but with no other tax in this roll.

70 In the date, there is something resembling a mu between the eta and the double stroke--a false attempt at a hasty double stroke or a second start on Merogi which was cancelled by the scribe himself?

71 For Philadelphia's location in the 2nd pagus of the Arsinoite Nome, cf. e. g. BGU IV 1049. It is curious that the scribe has omitted the word $\delta \rho \alpha \chi \mu \dot{\alpha}_{5}$ here and in line 73 before the number.

82 For diatyposis, of. $63 \mathrm{n}$.

$87-88$ For the measure, see $39-40 \mathrm{n}$, $133 \mathrm{n}$.

91 Cf. $7 \mathrm{n}$.

$105 \mathrm{As}$ it seems, both Posis and Paesis were sons of Tasouk, but the point of the patronymic may

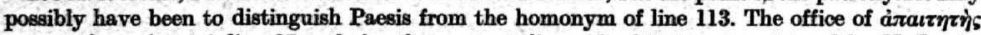

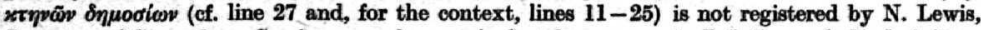

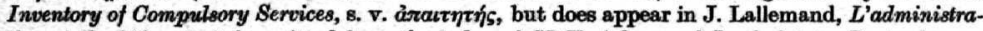
tion civile, $209 \mathrm{n}$. 3; it is omitted from the index of $S B$ V. A komarch/kephalaiotes Posis also occurs in line 47 (cf. note ad loc.). A kephalaiotes Pasis occurs in 112, 153, 155, and 160. We cannot tell whether Posis/Pasis are just variants of one name borne by one man, or two different people; cf. supra, p. 59-60.

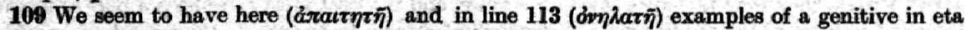

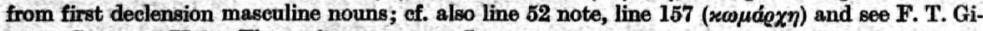
gnac, Grammar II 14. The $\pi \varrho \delta s$ seems superfluous.

111-114 The syntax of this receipt is somewhat confused, since in 113 Paesios in presumably in the same function as Pasis in 112; if his name had been in the nominative and siá transposed to after it, the receipt would make better sense. Each kephalaiotes got through Ason 4, $500 \mathrm{dr}$., but only Paesios (evidently) got one artaba of barley, valued at $1000 \mathrm{dr}$. For grain prices in this period see R. S. Bagnall, Currency and Inflation in Fourth-Century Egypt, forthcoming.

118 For the advance payment ef. $66 \mathrm{n}$.

123 For indiction 23, see $C S B E$ 3. For the reading of the tax, cf. $63 \mathrm{n}$.

124 Cf. $66 \mathrm{n}$.

126 For the charge for unslaked lime see P. Cair. Isid. $59.28 \mathrm{n}$., where it was suggested that this term would be found in the present passage.

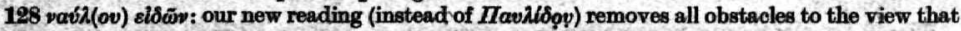
Thaeis was the wife of Harpokration (cf. Kase's remarks, P. Princ. Roll, p. 2, and supra, p. 58). For the tax, see P. Cair. Isid. 51. 2 n.

129 We have not succeeded in reading what follows the indiction; $k \omega(\mu \eta \tilde{r} \omega)$ (cf. lines 251, 257) does not seem likely.

133 For the measure, see P. Col. VII 154.27, 37 n., and of. supra, 39-40 n.

136 Venaphris is an intermediary who has paid some of the taxes due from Thaeis and Harpokration; possibly he is to be seen as a lessee. In lines 215, 217, he again appears, and the total amount paid is about the same as here.

154 Same man as in lines 197, 239 (in both an Asoeis sitologos occurs)?

166 For Gounthos, cf. supra, p. 59.

167 Cr. $109 \mathrm{n}$.

159, 101 It is remarkable that the entry for Thoth 8 stands before the entry for Thoth 6; perhaps the latter was written retrospectively or copied from an ostrakon.

163 We do not know what this line stands for; a reading Agóge[s does not seem possible.

171 Cf. $71 \mathrm{n}$.

176 CE. CSBE 3.

183-184 For the consuls, see J. F. Gilliam, Historia 16 (1967) 252-254.

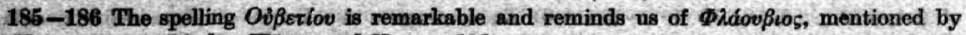

B. Meinersmann, Die lat. Wörter und Namen, 112. 
188 For the tax on seagoing ships see the literature cited in BASP 13 (1974) 34 and A. J. M. Meyer-Termeer, Die Haftung der Schiffer, 168 n. 113; see also P. Col. VII 130 introd.

189 This is the first occurrence of denarii in this tax roll. Kase suggested connecting this fact with a monetary reform which Miekwitz had proposed for this period, but this cannot be supported. On currency in this period, ef. the monograph by Bagnall cited in $111-114 \mathrm{n}$.

191-196 Cf. the payments made in lines $73-81$; cf. supra, p. 58 .

202-203 Cf. CSBE 3.

204 The payment was probably 49 art. plus $10 \%$; ef. $41-42$ n.

206 For the denarius per modium of. the remarks of A. J. M. Meyer-Termeer, Die Haftung der Schiffer, 14 and 46 n. 189.

915 Cf. $136 \mathrm{n}$. for Venaphris; for the amount paid of. $204 \mathrm{n}$.

217 Cf. $136 \mathrm{n}$.; the amount for barley was 30 art. plus $10 \%$.

233 Cf. line 243 and supra, p. 58.

283 Here, as in $265-266$, the denarius charge has been tacked on as a kind of afterthought after the consular date; it refers properly to the amount in line 235.

243 Cf. line 233 and supra, p. 58.

244 The 33 artabas of wheat was 30 plus $10 \%$.

251 For politai, citizens of the metropolis of the nome, see A. E. R. Boak, JEA 40 (1954)

$11-14$ and P. Cair. Isid. 9 introd., pp. 76-77; ef. 129 n.

257 See $251 \mathrm{n}$.

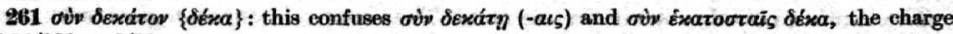
of $10 / 100$ or $1 / 10$.

262 For the tax on insolvent accounts, of. D. H. Samuel in Le monde grec: Hommages Cl. Préaux, 611-621, esp. 620-621. Samuel does not refer to this papyrus in her note $620 \mathrm{n}$. 4. It seems remarkable enough that a delivery in kind, rather than a payment of money, is recorded here.

263 The total mentions a sixth of an artaba which was not recorded when the amount was given before. The place of $\delta \mu \sigma \tilde{v}$ is a bit odd, also; one expects it after the verb. Evidently some correction has taken place.

265-266 C.. $238 \mathrm{n}$.

268 Cf. Lallemand, L'adm. civ., 202, for epibole. We have not been able to find a convincing reading for the word following rat. Evidently some unknown tax is meant.

\section{Appendix}

\section{Multiple-receipt Tax Rolls}

In P. Col. VII, pp. 70-72, there is a discussion of the manner in which seribes writing tax receipts used the space on rolls as they came to write successive receipts at different times. The principles set out there were used to analyze the main Karanis rolls in that volume and in $P . N Y U$; we have extended this analysis to the Princeton roll above, p. 55. It seems to us worth adding by way of further illustration some comments on other fourth-century tax documents longer than one column. A number of them are short or otherwise very straightforward, but a few ñeed more extended discussion.

\section{P. Sakaon 15}

The receipts of Column i, dated to $8-26$. ii. 308, were written later than Column ii (3. ii. 308), unless one wants to assume that "III Non. Feb." is a scribal error for "III Non. Mart." (= 5. iii. 308). Column ii may simply have been written first, then the blank left margin used for Column i. 


\section{P. Sakaon 17}

All receipts are, so far as the data are preserved, written in chronological order. The day numeral is lost for ii. $29-32$; the preceding receipt is 18. vi. 308, and 29-32 may come from the next day.

\section{P. Sakaon 19}

Column ii. 13-25 includes receipts dated to 1-31. x. 315; in iii there are receipts from iii-v. 316. Column ii. $26-28$ has a receipt of 30 . iii. 316, obviously added after iii. 29-32 was written but before iii. 33-35 (iii. 316 and 24. iv. 316, respectively).

\section{P. Sakaon 21}

The receipts in Column.i. 12-22, 23-25 $(9,12$.ii. 320) were written later than Column ii (31. xii. 319), possibly even later than Column iii (date lost).

\section{$P$. Sakaon 22 and 23}

All receipts are written in chronological order.

\section{P. Cair. Isid. 41}

The text is a complex one in arrangement. The receipts in chronological order are:
a. 14. vi-vii/viii. 302 (iii. $28-36$ )
b. $31 . x .302$ (ii. 13-27)
o. $30-31$. xii. 302 (iii. $37-38$ )
d. 6. ii. 303 (iii. 39)
e. 28. iii. 303 (iii. 40 )
f. 2. vii. 303 (v. $50-56$ )
g. 14. vii. 303 (i. 6-12)
h. 21. xii. 303 (iii. 41)

i. 12. ii-?.?.304 (iv. 42-49)

j. 28?-13. viii. 304 (vii. 65-74)

k. 1. iv. 305 (vi. $57-64$ )

1. 23. vi. 305 (vii. $75-76$ )

m. 23. vii. 305 (vii. 76-78)

n. 23. vii. 305 (viii. $79-80$ )

o. ?.?. 312 (ix. 88-95)

p. 15. viii, 312 (x. 96-108)

The date of $i .1-5$ is lost; the date of viii. $81-87$ is unknown, and receipt " $p$ " may have been written earlier than receipt " 0 ".

It looks as if the scribe of the first receipt started leaving a large part of the initial section of the roll blank. The next writer filled up some of this space (we do not know when Column $i$ was begun), and after some further writing in iii, Column $v$ was begun. Some while later, a scribe wrote in the upper part of vii, and the following year again the space left in between was filled in (vi). There was space vacant at the foot of vii, however, and that came next; then viii, ix, and $x$ in order. It does not seem that rearranging fragments to achieve a less disturbed order is possible, to judge from the editors' description.

\section{P. Cair. Isid. 47}

The soribe finst wrote i. 1-8 and ii. 15-22 (both dated to 18. vi. 309), added below each receipt a new receipt dated to 23. vi. 309 (i. 9-14 and ii. 23-27), then filled Column ii with two receipts both dated to 10 . vii. 309 (lines $28-31,32-37$ ) and finally added iii. 38-54 (26. viii. 309).

\section{P. Cair. Isid. 53 and 59}

All receipts are written in chronological order. In 59 , the receipts in iii are from the same year but lack exact dates; they could thus conceivably be earlier than ii, which has receipts on 9 and 17. vii. 318, but that cannot be demonstrated.

P. Cair. Isid. 61

All receipts are in chronological order except for i. 8-11 (24. vi. 323), which falls between iii (24, v. 323) and iv (27. vii. 323) and poses no problem. 


\section{P. Mert. II 88}

The organization in this roll is rather complex, particularly in the second half of the roll, in which the writers alternated between one side and the other of the half, working toward its center, as can be seen from the tabulation below.
A. D. 298
A. D. 299
A. D. 300
A. D. 301
9. ii: ii. $1-8$
4. $\mathrm{v:} \mathrm{ix}$
8. vi: xi. $1-6$
5. i: xiv. 6-9
6. iii: iv
3. viii: $x$
8. vii: xvi. 1-2
?14. $i i$ : $x i .7-9$
1. v: ii. $9-10$
7. viii: xviii
23. viii: xiii
25. vi: v. $1-8$
13. ix : xvii
10. viii: $x v$
6. ii: xi. $10-14$
14. vii: v. 9-10
26. $x$ : xiv. 1-5
21. vii: vi. 1-6
1. xii: xvi. 3-8
20. viii: vii
24. x: viii
?12. xi: vi. 7-9
11. xii: xi. $6-7$

Column $\mathrm{i}$ lacks an indication of the julian year in which the receipt was written (297 or 298?).

Apart from the curious pendulum-like action in the second part, the ordering of receipts follows established patterns fairly closely. A few details deserve notice. Column ii, which does not have a date, seems to have been meant as some sort of sequel to ii and squeezed in between $\mathrm{ii}$ and iv, as one can see from the plate. In v. 9, the editors' reading $x\left(\alpha{ }^{\prime}\right)$ should instead be $x^{-}$, i. e. Epeiph 20 . The editors dated the receipts in xi to 299 and 300 : but cf. J. D. Thomas, BASP 15 (1978) 145 n. 57, for the dating used above. In our view, xii belongs to 301 as well. The order of receipts in xi, with 7-9 seemingly 8 days later than $10-14$, is puzzling. The first one, dated to Mecheir 20, could possibly instead date to the 2nd, reading beta instead of kappa; the reading is possible but not compelling.

\section{P. Panop. Käln 19}

This register of receipts is written in codex form rather than in roll form, so that the type of analysis used here is not applicable. The editors discuss the distribution of receipts in their introduction.

\section{P. Lips. 84}

The organization of this roll is also rather complex. The following chart shows the chronological distribution of receipts insofar as that can be established (Column ii lacks absolute dates, dealing with the crop of 301. In Column iii. 1-6, we have assumed a year from the order within the receipts).
A. D. 301
A. D. 302
26. viii: : iii. 1-6
1. v: iii. 18-21
13. ix: iii. $12-17$
24. x: i. $15-17$

xi-xii: i. 4-14

A. D. 303

10. ii: iv. $1-4$

25. ii: iv. $5-8,9-10$

10. iii: iv, $11-15$

28. iii: v. $1-5$

iv/v: v. 24-26

29. iii: v. 6-10 27. v: vi. 1-4

11. iii: iv. $16-19$

30. iii: v. $11-15$

10. vi: vi. $5-7$

31. iii: v. $16-20$

24. vi: vi. $8-11$

12. iii: iv. $20-23$

8. iv: v. $21-23$

25. vi: vi. $12-13$

26. iii: iv. $24-29$

9. iv: vi. $14-18$

19. viii: vi. $19-26$

ii/iii: $i$. 1-3

11. iv: iii. 7-11

30. $x$ : vii. $1-7$

A. D. 305

11. ii: vii. $8-13$ 
The chart implies that the date of $v .11-15$ is not Pharmouthi 14 (9. iv) but Pharmouthi 4 . On the basis of a photograph kindly provided by $J$. D. Thomas, this seems a possible reading. There is an ink trace after the month name, but it may be a curved line such as one finds in a number of texts after month names, rather than an iota. For the month in v. 24-26, cf. BLI 212; this reference needs to be added to RFBE 25.

\section{P. Charite 15}

This text contains 2 columns each consisting of three receipts. The main dating criterion for establishing the julian year in which these texts were written is, apart from prosopographical arguments, the indictions which denote the fiscal years for tax payments. The receipts are dated as follows:

a) i. $1-10$ : for ind. $16=2,15=1$, Pharmouthi 19

b) i. 11-14: for ind. 5, Mecheir 25

c) i. 15-20: for ind. 15, Epeiph 15

d) ii. 21-28: for ind. ?, Epeiph 18

e) ii. 29-34: for ind. 15, Epeiph 30

f) ii. $35-41$ : for ind. 3, Mesore 2

It is striking that receipts $c, d$, and e were written in the month Epeiph, and $f$ just after its end; and that receipts $d, e$, and $f$ were all signed by the same gnoster Polis. Moreover, these same three were probably written in the same hand (the editor's distinction of a fifth hand for $f$ is probably not to be followed). If one assumes that the succession of month dates in Epeiph and Mesore is not accidental, but that they come in the same julian year, one must draw the conclusion that receipts $c, d$, and e refer to back-payments for the same indictions even though these are not indicated as such (cf., however, $P$. Col. VII, pp. $73-74$ on the sequence of indictions in P.NYU 11 a). In that case, the date of receipts $c, d$ and e must be the same julian year as that suggested for receipt $f$. We think that one can establish the following dates for these receipts:

a: 14. iv. 329

b: 20 . ii. 332

c f: 9. vii. 329 d: 12. vii. 329

e: 24 . vii. 329

f: 26 . vii. 329

The plate shows that receipt $b$ was squeezed in between receipts $a$ and $c$ and covered part of the earlier writing. 